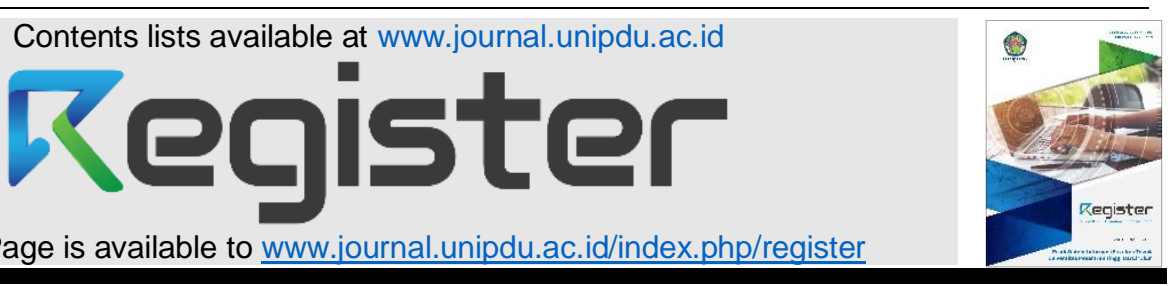

Research article

\title{
Spatial dynamics model of land use and land cover changes: A comparison of CA, ANN, and ANN-CA
}

\author{
Moh. Dede ${ }^{a, d^{*}}$, Chay Asdak ${ }^{b, c}$, Iwan Setiawan ${ }^{c}$ \\ a Department of Environmental Science, Universitas Padjadjaran, Bandung, Indonesia \\ ${ }^{b}$ Department of Agricultural Engineering, Universitas Padjadjaran, Sumedang, Indonesia \\ c Department of Geography Education, Universitas Pendidikan Indonesia, Bandung, Indonesia \\ 'Center for Nuclear Energy System Assessment, National Nuclear Energy Agency (BATAN), Jakarta, Indonesia \\ email: ${ }^{a}{ }^{*}$ m.dede.geo@gmail.com, ${ }^{b}$ casdak@unpad.ac.id, ciwansetiawan@upi.edu \\ * Correspondence
}

\section{A R T I C L E I N F O}

\section{Article history:}

Received 1 March 2021

Revised 11 April 2021

Accepted 11 April 2021

Available online 15 June 2021

\section{Keywords:}

Cirebon's peri-urban

Logistic regression

LULC changes

spatial dynamics

Please cite this article in IEEE style as: M. Dede, C. Asdak and I. Setiawan, " Spatial dynamics model of land use and land cover changes: A comparison of CA, ANN, and ANN-CA," Register: Jurnal Ilmiah Teknologi Sistem Informasi, vol. 8, no. 1, pp. 38-49, 2022.

\section{A B S T R A C T}

Land use and land cover (LULC) changes through built-up area expansion always increases linearly with land demand as a consequence of population growth and urbanization. Cirebon City is a center for Ciayumajakuning Region that continues to grow and exceeds its administrative boundaries. This phenomenon has led to peri-urban regions which show urban and rural interactions. This study aims to analyze (1) the dynamics of LULC changes using cellular automata (CA), artificial neural network (ANN), and ANNCA; (2) the influential factors (drivers); and (3) change probability in the period 2030 and 2045 for Cirebon's peri-urban. We used logistic regression as quantitative approach to analyze the interaction of drivers and LULC changes. The LULC data derived from Landsat series satellite imagery in 1999-2009 and 2009-2019, validation of dynamic spatial model refers to 100 LULC samples. This research shows that LULC changes are dominated by built-up area expansion which causes plantations and agricultural land to decrease. The drivers have a simultaneous effect on LULC changes with r-square of 0.43 , where land slope, distance from existing builtup area, distance from $\mathrm{CBD}$, and accessibility are significant triggers. LULC simulation of CA algorithm is the best model than ANN and ANN-CA based on overall accuracy and overall accuracy $(0.96,0.75,0.73$ and $0.95,0.66,0.66$ respectively), it reveals urban sprawl through the ribbon and compact development. The average probability of built-up area expansion is 0.18 (2030) and 0.19 (2045). If there is no intervention in spatial planning, this phenomenon will decrease productive agricultural lands in Cirebon's peri-urban.

Register with CC BY NC SA license. Copyright @ 2022, the author(s)

\section{Introduction}

Land is a resource formed by biotic and abiotic components on the earth's surface. The land resource is manifested by humans in the form of land use and land cover (LULC) for their activities such as agriculture, settlement, infrastructure, fisheries, and others [1, 2, 3]. The human need for land always increases along with population growth and regional development. Thus its existence is dynamic spatially and temporally [4]. The LULC dynamics cause massive changes of function in agricultureproductive lands into built-up areas, in a certain period, LULC dynamics are able to change the environmental conditions surrounding it. The LULC dynamics, originally, is a local environmental issue. However, it has global implications because the patterns and characteristics of changes in each region are influenced by many factors, both biogeophysical and socio-cultural $[5,6]$. 
Biogeophysical factors such as slope, distance from the rivers, soil type, disaster-prone, and resource availability are considered in determining LULC development [7]. On the other hand, sociocultural factors also act as reinforcement for decisions related to LULC, such as central business district (CBD), population dynamics, accessibility, security, and political regulation [8]. Judging from its characteristics, biogeophysical factors have static tendency and will change in a long time if following human scale, different things actually happen to socio-cultural factors that are dynamic and varied [9]. LULC changes in developing countries are driven by population growth which puts pressure on land. Every year, the population of Indonesia increases about 1.8 percent; it will increase to 2.1 percent in 2030 due to demographic bonus [10]. This phenomenon has implications for a large number of agricultureproductive lands that have turned into built-up areas for housing, industrial areas, and infrastructures to support human life [11, 12]. Currently, agricultural land conversions in Indonesia reach 22,000 110,000 hectares with Java Island is the main concentration [13]. It can be found in several areas around the growth center in West Java and occurs in new peri-urban areas in Bogor Regency, Bekasi Regency, Bandung Regency, West Bandung Regency, Cianjur Regency, and Cirebon Regency.

In Cirebon City, built-up area increasing is an implication of its role as the growth center for Cirebon-Indramayu-Majalengka-Kuningan (Ciayumajakuning) Region. This situation is driven by new industrial and residential areas demand, besides the suitable land is difficult to find in Cirebon City (low supply) and causes the development-oriented towards Cirebon Regency as peri-urban [14]. Apart from regional interactions, the peri-urban area also has relatively large areas, although agriculturalproductive lands are dominant. The built-up area expansion, as the main parameter of urban development, has a potential to reduce vegetated areas and expand beyond administrative boundaries, it causes urban sprawl. The Cirebon's peri-urban consists of five sub-districts are located in Cirebon Regency [15]. The urban sprawl will change the agricultural landscape towards industry, whereas Cirebon Regency has a comparative advantage in the agricultural sector.

The LULC dynamics on spatially-temporally terms can be reviewed by involving many influential factors [16]. LULC changes observation in peri-urban can use satellite imageries data as input for a dynamic system. LULC dynamic modeling has an advantage and capability of studying changes in probability and its influential factors (drivers), also produce scenarios based on time and space trends [17]. In general, this modeling can refer to cellular automata (CA) and artificial neural network (ANN) models, although both have different characteristics and are greatly dependent on geographic variability. CA has the advantage of changing according to the pixels or cell conditions around it, whereas ANN is able to multiply cells further away from its origin and become a non-linear pattern [18, $19,20]$. Both ANN and CA are able to generate probability values, and we can modify these models with geographic information systems to obtain dynamic spatial modeling. Therefore, this study aims to analyze (1) the dynamics of LULC changes using CA, ANN, and ANN-CA; (2) the influential factors (drivers); and (3) the change probability in Cirebon's peri-urban for 2030 and 2045.

\section{Method}

\subsection{Area of interest}

This research was conducted in Cirebon's peri-urban, West Java, Indonesia. Cirebon's peri-urban is a buffer area and surrounding Cirebon City which consists of 5 (five) sub-districts, is directly adjacent to Java Sea, and located in UTM zone 49 southern hemisphere. The peri-urban region is delineated based on five parameters, i.e. built-up ratio, accessibility (road density), population density, and distance from the CBD [15]. Early indications of this peri-urban in all sub-districts surrounding Cirebon City; however, regionalization with the ecoregion approach has found this only covers 5 (five) sub-districts and 48 villages. Cirebon's peri-urban has $76.83 \mathrm{~km}^{2}$ area, and it divided into $59.20 \mathrm{~km}^{2}$ in the west and 17.63 $\mathrm{km}^{2}$ in the east (Fig. 1). The region has its own uniqueness, because directly adjacent and separate to Cirebon City in the middle. However, not all villages in Talun and Mundu Sub-District are peri-urban regions.

\subsection{Data for LULC and drivers}

LULC changes data were obtained from Landsat series imagery for 1999 (Landsat-7 ETM +), 2009 (Landsat-5 TM), and 2019 (Landsat-8 OLI), single scene, respectively. The satellite image criteria must have cloud cover below five percent and be recorded during the dry season. Data on LULC changes 
were also reinforced by Sentinel-2 MSI and CNES-Airbus (d/h CNES-Astrium) imageries as references for this classification. Analysis of LULC changes begins with remote sensing images through visual interpretation according to interpretation keys [21, 22]. We combined 543 bands for Landsat- $5 \mathrm{TM}$ and Landsat-7 ETM, also 654 bands combination for Landsat-8 OLI, these combinations are false colors. The band composition makes it easy to identify LULC from appropriate wavelengths [23]. LULC types separated into water bodies, non-vegetated, agriculture, built-up areas, mangroves, marsh, salts and fisheries, and plantations. Built-up areas contain urban settlements, roads, industries, and others infrastructures. Mangroves are identified by spectral values which are similar to plantations, but they are located near beach or river estuaries [24, 25]. The multi-temporal LULC information would be analyzed for changes and comparing using the overlay method. The rate of changes in area refers to LULC types polygon according to period I (1999-2009) and period II (2009-2019). LULC changes are generally influenced by biogeophysical and social-economic factors (drivers) [26], as shown in Table 1. These factors that have the potential to drive LULC changes need reclassification based on criteria are presented in Table 2.

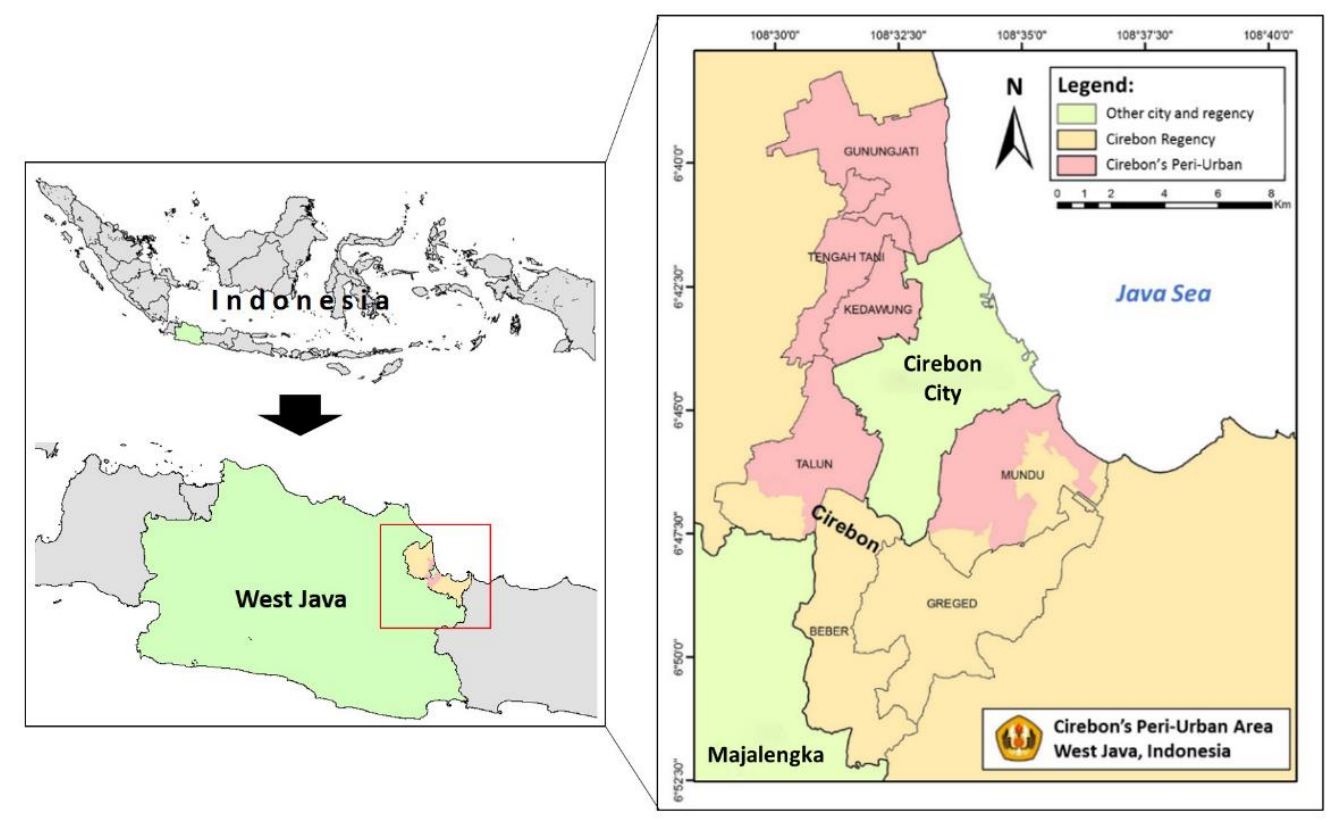

Fig. 1. Area of interest [15]

Table 1. Drivers data for LULC changes

\begin{tabular}{|c|c|c|c|}
\hline Driver & Source & Indicator & Information \\
\hline Land slope & $\begin{array}{l}\text { Shuttle Radar Topographic Maps } \\
\text { (SRTM) }\end{array}$ & Slope analysis & $\begin{array}{l}\text { Van Zuidam's } \\
\text { classification }\end{array}$ \\
\hline $\begin{array}{l}\text { Distance from the } \\
\text { rivers }\end{array}$ & $\begin{array}{l}\text { Indonesian Ministry of } \\
\text { Environment and Forestry (KLHK) }\end{array}$ & $\begin{array}{l}\text { Buffering from river } \\
\text { networks }\end{array}$ & Euclidean distance. \\
\hline $\begin{array}{l}\text { Distance from the } \\
\text { existing built-up } \\
\text { area }\end{array}$ & Landsat series imagery (USGS) & $\begin{array}{l}\text { Buffering from the } \\
\text { existing built-up area }\end{array}$ & Euclidean distance. \\
\hline Distance from CBD & $\begin{array}{l}\text { Provincial Government of West } \\
\text { Java }\end{array}$ & $\begin{array}{l}\text { Buffering from main } \\
\text { central business } \\
\text { district (CBD) }\end{array}$ & $\begin{array}{l}\text { Buffering dilakukan } \\
\text { dengan metode Euclidean } \\
\text { distance. }\end{array}$ \\
\hline Population density & $\begin{array}{l}\text { Indonesian Statistical Agency } \\
\text { (BPS) }\end{array}$ & Residential density & $\begin{array}{l}\text { Ratio of population and } \\
\text { built-up area }\end{array}$ \\
\hline Accessibility & Openstreetmaps (OSM) & Road density & $\begin{array}{l}\text { Ratio of street lengths and } \\
\text { area }\end{array}$ \\
\hline Disaster risk & $\begin{array}{l}\text { National Agency of Disaster } \\
\text { Management (BNPB) }\end{array}$ & $\begin{array}{l}\text { Multi-level disaster } \\
\text { risk }\end{array}$ & $\begin{array}{l}\text { Digitation from BNPB's } \\
\text { Disaster Risk Map }\end{array}$ \\
\hline
\end{tabular}




\subsection{Data analysis}

This study uses a quantitative approach and refers to logistic regression model to determine the interaction between drivers on LULC changes. In this regression model, LULC changes data converted into discrete numbers to fit the criteria for the dependent variable in Eq. 1. We test the feasibility of model using the -2 log-likelihood, Nagelkerke r-square, and Hosmer-Lemeshow tests are provided by statistical computing software. -2 log-likelihood value and r-square were significant if these have pvalue less than 0.05, whereas vice versa for Hosmer-Lemeshow [9]. This model is useful for compiling the probability of LULC changes according to scenarios from us,

$$
\ln \left(\frac{P_{i}}{1-P_{i}}\right)=\alpha+\beta_{1} X_{1}+\beta_{2} X_{2}+\ldots \beta_{n} X_{n}
$$

where $\ln$ is natural logarithm, $P_{i}$ is probability value, $\alpha$ is the regression constant, and $\beta$ is predictor coefficient for independent variables.

Table 2. Drivers reclassification

\begin{tabular}{|c|c|c|c|c|c|c|c|}
\hline Score & $\begin{array}{c}\text { Land slope } \\
(\%)\end{array}$ & $\begin{array}{l}\text { Distance } \\
\text { from the } \\
\text { rivers (m) }\end{array}$ & $\begin{array}{l}\text { Distance from } \\
\text { existing built- } \\
\text { up area (m) }\end{array}$ & $\begin{array}{c}\text { Distance } \\
\text { from CBD } \\
\text { (m) }\end{array}$ & $\begin{array}{l}\text { Population } \\
\text { density } \\
\text { (person per } \\
\text { km²) }^{2}\end{array}$ & $\begin{array}{c}\text { Accessibility } \\
(\mathbf{k m} \text { per } \\
\left.\mathbf{k m}^{2}\right)\end{array}$ & $\begin{array}{c}\text { Disaster } \\
\text { risk }\end{array}$ \\
\hline & $\mathrm{X}_{1}$ & $X_{2}$ & $\mathrm{X}_{3}$ & $\mathrm{X}_{4}$ & $X_{5}$ & $X_{6}$ & $X_{7}$ \\
\hline 1 & $>30-45$ & $>1000$ & $>2000$ & $>4000$ & $0-3000$ & $0-2.5$ & Very high \\
\hline 2 & $>15-30$ & $>750-1000$ & $>1000-2000$ & $>2000-4000$ & $>3000-4000$ & $>2.5-5.0$ & High \\
\hline 3 & $>8-15$ & $>500-750$ & $>500-1000$ & $>1000-2000$ & $>4000-5000$ & $>5.0-7.5$ & Medium \\
\hline 4 & $>3-8$ & $>250-500$ & $>250-500$ & $>500-1000$ & $>5000-6000$ & $>7.5-10.0$ & Low \\
\hline 5 & $0-3$ & $0-250$ & $0-250$ & $0-500$ & $>6000$ & $>10.0$ & Very low \\
\hline
\end{tabular}

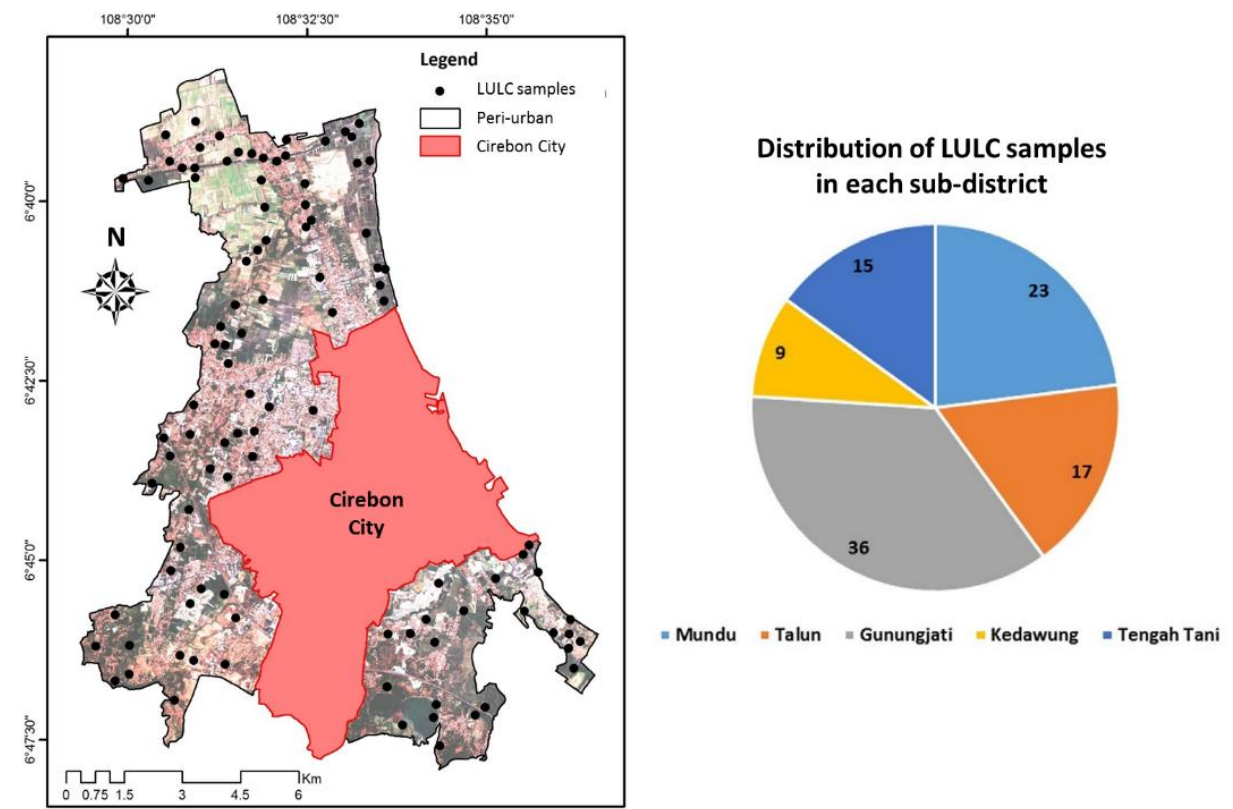

Fig. 2. Sampling location for LULC models

The validation of LULC dynamic model results refers to 100 sample points based on nonprobability sampling, and they are considered easy access to locations (Fig. 2). The result is entered in an error matrix, models are suitable if it meets requirements - minimum 80 percent [27]. The validity level of forecasting data from CA, ANN, and ANN-CA based on overall accuracy and overall Kappa [28]. We performed CA and ANN model using Land Change Modeler (LCM), while ANN-CA considered Model for Land Use Change Simulation in QGIS. The best model will be used as a forecasting algorithm in 2030 and 2045. Meanwhile, for the scenario of LULC change in the future, we divide it into three scenarios as follows.

a. The first scenario, in 2030 and 2045, all drivers are declared to be constant as in 2020 .

b. The second scenario, the population density will increase in accordance with BPS projection in 2030 and 2045, whereas the other drivers are constant.

c. The third scenario, the population density will increase according to BPS projection and accompanied by increasing accessibility, distance from existing built-up area, and distance from 
CBD (1.5 times in 2030 and double in 2045 refers to the author's interpretation of Metropolitan Cirebon Raya Planning from West Java Provincial Government and Regional Spatial Planning of Cirebon Regency), while the other drivers are simulated to be constant.

\section{Results and Discussion}

\subsection{LULC dynamics in Cirebon's peri-urban}

Cirebon's peri-urban experienced very dynamic LULC changes during 1999-2019, especially built-up areas developed from 9.38 to $24.82 \mathrm{~km}^{2}$ - growth 164.52 percent. This increase led to a reduction in agricultural land and plantations (Table 3). In the same period, agricultural land decreased by $6.07 \mathrm{~km}^{2}$, it was similar to plantations decreased by $9.95 \mathrm{~km}^{2}$. Built-up area increased in 2009-2019 with difference of $2.24 \mathrm{~km}^{2}$ from the last period. In terms of distribution, built-up areas are increasing and closer to Cirebon City (Fig. 3). This condition indicates that there is an urban sprawl towards peri-urban in

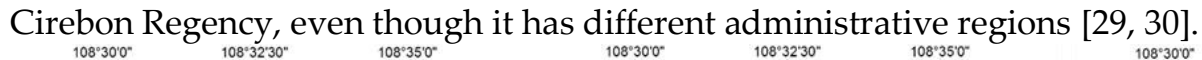

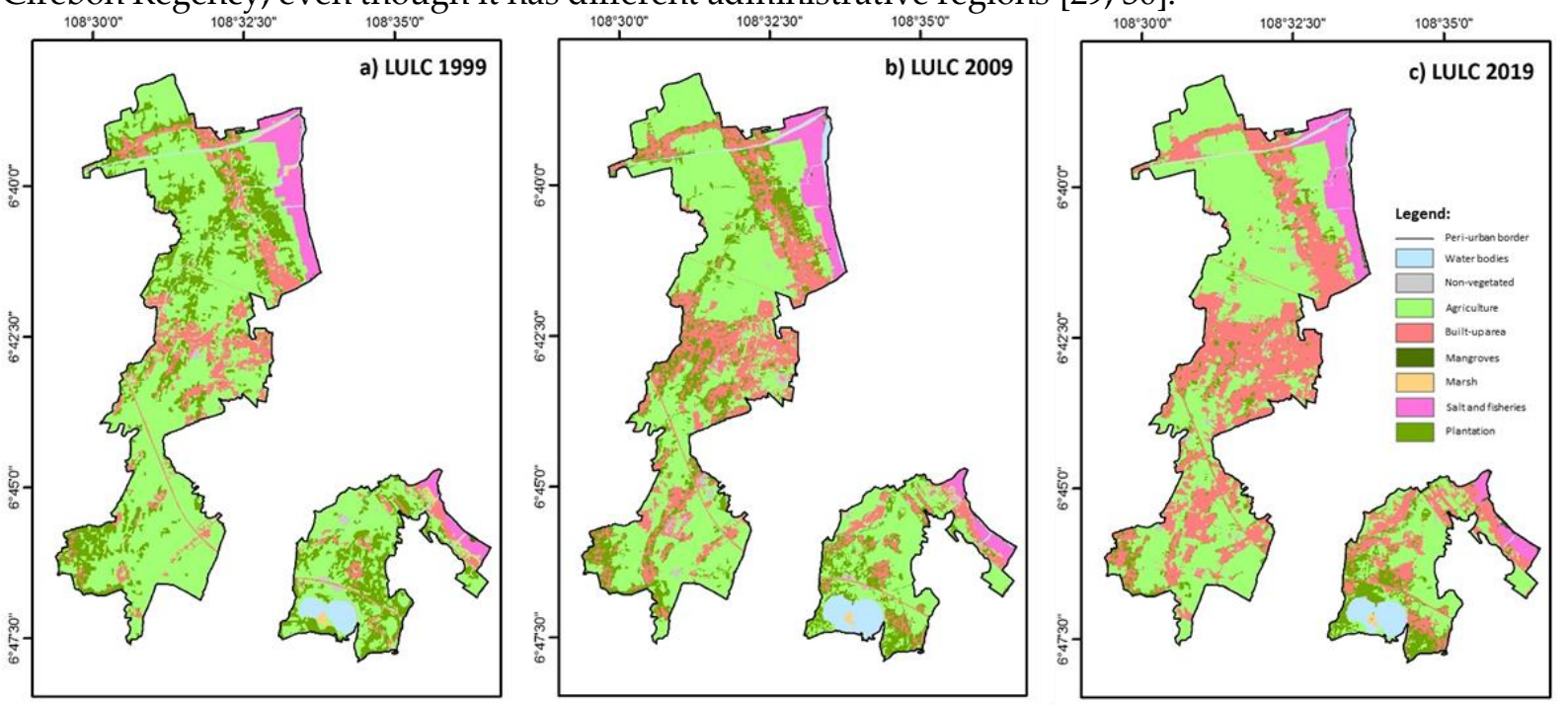

Fig. 3. LULC in Cirebon's peri-urban 1999-2019

The peri-urban as a buffer for Cirebon City has undergone a landscape transformation, characterized by expansion of built-up areas. LULC changes resulted in agricultural land conversion into other types (marsh, non-vegetated, or grasslands), which ended in built-up formation as a process that seemed to globally $[9,31,32]$. This process is understandable because peri-urban development into a city is actually not only occur in Cirebon, but also takes place globally in many metropolitan regions that have potential for massive economic development. In today's era, more than half of Indonesia's population and the world have lived in cities, where in the future, a population spike will also be centered in urban $[33,34,35]$. Population concentration not only occurs that cities are able to attract residents to migrate, but also from the physical urbanization process - a transformation of rural into urban landscape.

Table 3. LULC dynamics in 1999-2019

\begin{tabular}{lrrrrrr}
\hline \multicolumn{1}{c}{ LULC type } & \multicolumn{3}{c}{ Area $\mathbf{( k m}^{\mathbf{2}}$ ) } & \multicolumn{3}{c}{ Gain and loss $\left(\mathbf{k m}^{\mathbf{2})}\right.$} \\
& $\mathbf{1 9 9 9}$ & $\mathbf{2 0 0 9}$ & $\mathbf{2 0 1 9}$ & $\mathbf{1 9 9 9 - 2 0 0 9}$ & $\mathbf{2 0 0 9 - 2 0 1 9}$ & $\mathbf{1 9 9 9 - 2 0 1 9}$ \\
\hline Water bodies & 2.057 & 2.764 & 2.195 & 0.707 & -0.569 & 0.138 \\
Non-vegetated & 0.454 & 1.252 & 0.753 & 0.798 & -0.499 & 0.299 \\
Agriculture & 44.564 & 40.082 & 38.499 & -4.482 & -1.584 & -6.066 \\
Built-up area & 9.384 & 15.984 & 24.822 & 6.601 & 8.837 & 15.438 \\
Mangroves & 0.065 & 0.084 & 0.224 & 0.019 & 0.139 & 0.158 \\
Marsh & 0.408 & 0.413 & 0.252 & 0.004 & -0.161 & -0.156 \\
Salts and fisheries & 3.930 & 3.894 & 4.067 & -0.036 & 0.173 & 0.138 \\
Plantations & 15.966 & 12.354 & 6.016 & -3.611 & -6.338 & -9.949 \\
\hline
\end{tabular}

In Cirebon's peri-urban context, this landscape transformation needs to be understood as more than just LULC changes. The peri-urban keeps the information about development concentration which direct towards the west. This process is taking place and influenced by Megapolitan Jakarta and Megapolitan Bandung, which have very good connectivity with Cirebon City. Transportation 
infrastructure presence such as toll roads, arterial/collector roads, railroads, and many public transportation routes is evidence [36]. A lot of productive agricultural land has been converted into built-up areas for residential, utilities, industrial, and other commercial areas. This change is accelerated due to the appearance of built-up areas patches between agricultural lands. It triggers LULC changes as nearing distance from existing built-up areas than in the previous period. These spots are emergence signs of leaf frog development that must be managed properly. Leaf frog development has a bad influence on urban development due to land fragmentation [37].

\subsection{Drivers for LULC changes}

After knowing the dynamics of LULC changes in Cirebon's peri-urban, especially regarding the expansion of built-up areas, which is increasingly widespread. We have analyzed the drivers that affect these changes, including land slope $\left(X_{1}\right)$, distance from the rivers $\left(X_{2}\right)$, distance from existing built-up areas $\left(\mathrm{X}_{3}\right)$, distance from $\mathrm{CBD}\left(\mathrm{X}_{4}\right)$, population density $\left(\mathrm{X}_{5}\right)$, accessibility $\left(\mathrm{X}_{6}\right)$, and disaster hazard $\left(\mathrm{X}_{7}\right)$ (Fig. 4). Logistic regression model is the best model for known factors driving LULC changes [9]. Without including independent variables - only using constant values, this model has an accuracy of 87.91 percent. Meanwhile, if all independent variables are involved, the accuracy reaches 88.3 percent as presented in Table 4 - an increase in accuracy by 0.4 percent. The logistic regression model involving independent variables has the ability (feasible) to predict LULC change, Hosmer and Lemeshow test shows a value of 3.80 with p-value more than 0.05 , it is supported by r-square value of 0.43 .
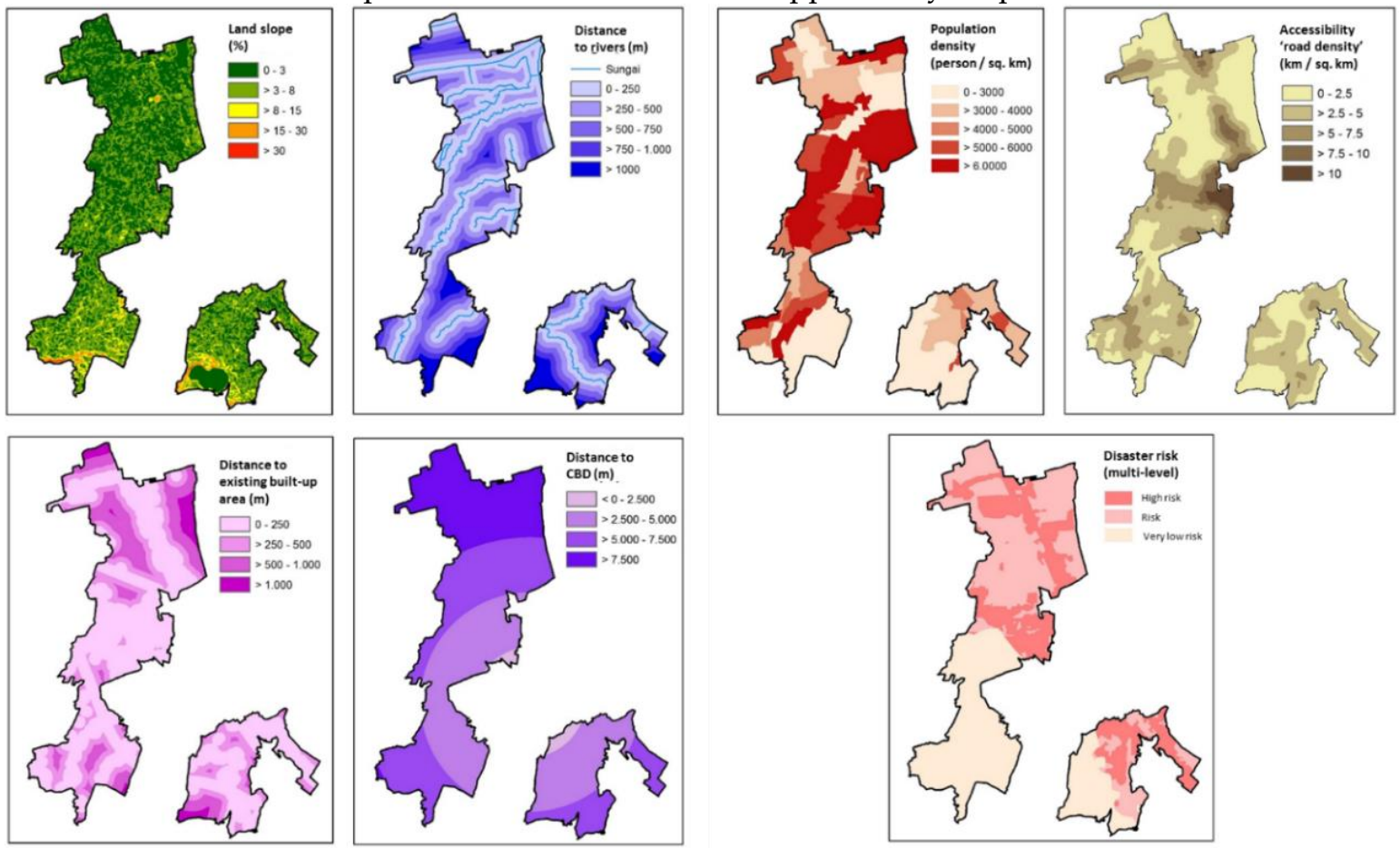

Fig. 4. Spatial distribution of LULC drivers

All independent variables (drivers) can simultaneously estimate LULC changes of 42.7 percent with epsilon of 57.3 percent, which means there are other factors that have not been defined. Even so, a low r-square value is a common phenomenon in logistic regression model, but it provided that the value is significant and meets goodness of fit because in many cases the highest $r$-square for the model is around 0.40 [38]. The logistic regression model shows that there are 4 (four) independent variables that have significant effect on LULC changes (built-up land expansion) in Cirebon's peri-urban such as X1, $X_{3}, X_{4}$, and $X_{6}$, as shown in Table 5 and Eq. 2. Referring to the p-value to know partial influence, there are four drivers that have a significant effect in succession, namely distance from existing built-up area $(0.05>0.00)$, land slope $(0.05>0.02)$, distance from CBD $(0.05>0.02)$, and accessibility $(0.05>0.03)$. The distance from existing built-up area $\left(X_{3}\right)$ as the strongest driver indicates that LULC changes are commonly influenced by social neighborhoods, where the community and developers will build new built-up areas for housing, industry, and other utilities closer to existing community. However, in certain cases, new built-up areas are deliberately presented further from the existing which causes 
agricultural land to become squeezed (sawah terhimpit) and puts socio-economic pressure on farmers [39].

$$
\ln \left(\frac{P_{i}}{1-P_{i}}\right)=-0,04959+0,14163\left(X_{1}\right)-0,00079\left(X_{2}\right)-0,01917\left(X_{3}\right)-0,00030\left(X_{4}\right)+0,00011\left(X_{5}\right)-0,29868\left(X_{6}\right)-0,04959\left(X_{7}\right)
$$

Table 4. Validation of logistic regression

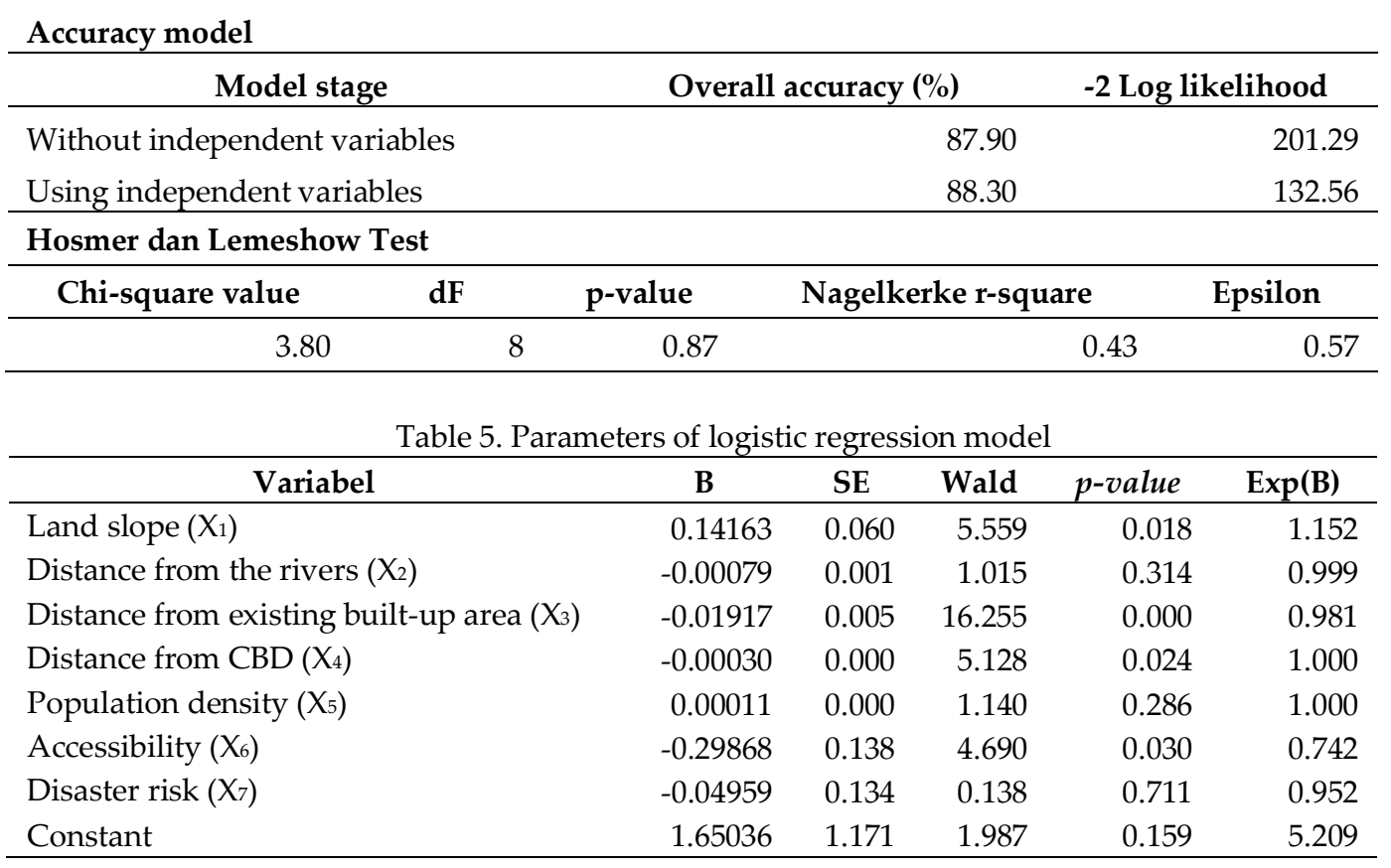

\subsection{LULC simulation and scenarios}

The LULC for the future can be determined through a spatial dynamic model based on machine learning and artificial intelligence algorithms such as artificial neural networks (ANN), cellular automata (CA), and ANN-CA (Fig. 5). In the case of Cirebon peri-urban, the best model for projecting LULC in 2030 and 2045 is cellular automata, as shown in Table 6 and Fig. 6. This model has overall accuracy of 0.96 and an overall Kappa of 0.95 - higher than ANN and ANN-CA models after being compared with existing LULC in 2020. These two values suggest that LULC dynamics with CA model is worthy accepted for further analysis, because it has high accuracy which is more than 0.80 [40] (Fig. 7 and Table 7). The CA model has accuracy advantage in predicting LULC, this is evidenced by its ability to predict almost all types of LULC in 2020, except for marsh. In other models, errors are found more varied in the area and LULC type. Even in ANN model, plantations have areas that are very different from the existing ones. Similar conditions also occur in ANN-CA model; this model only accurately predicts plantation around Situ Patok (Mundu Sub-District). Both the ANN and ANN-CA have considerable errors in predicting agricultural land. CA is suitable for predicting the LULC dynamic in peri-urban Cirebon, where urban sprawl occurs slowly and shows minimal symptoms of sudden built-up expansion. CA model has succeeded in maintaining the existence of plantations in a proportional manner that is scattered around the built-up land and agricultural land. This fact reinforces that CA model is indeed suitable for analysis of spatial phenomena with propagation patterns [6, 41].

Integration of logistic regression with CA produces a probability scenario for LULC changes in the future $[42,43]$. In the first scenario, it is assumed that all drivers are constant, as happened in 2020, because the government and stakeholders are capable to undertake adaptive control. This scenario has implications for built-up expansion probability tends to be low. In the first scenario, the probability of built-up expansion between 2030 and 2045 is quite different. The probability value in 2045 is higher than the previous projected period. Meanwhile, in the second scenario, all drivers except population density $\left(X_{5}\right)$ is constant. This scenario requires the population density to be dynamic in accordance with the population growth projection from BPS. The second scenario shows that the probability expansion of built-up areas increasing than the first scenario. This increase is minor and only occur in three subdistricts, namely Kedawung, Mundu, and Tengah Tani. Population density is an insignificant factor for predictive built-up area. It is certainly different from the third scenario, which involves all drivers that 
have significant influence with dynamic characteristics. In the third scenario, the probability increases rapidly in 2030 and 2045 periods. The probability in 2030 is higher in Kedawung and Tengah Tani than in other sub-districts; it shows that in the short and medium-term, built-up area development will still be concentrated in the west of Cirebon City [36]. It is different with 2045 period, where the built-up expansion probability will increase in all sub-districts and imply a decrease in agricultural land found in Cirebon's peri-urban on the current ecoregion boundary (Fig. 7).
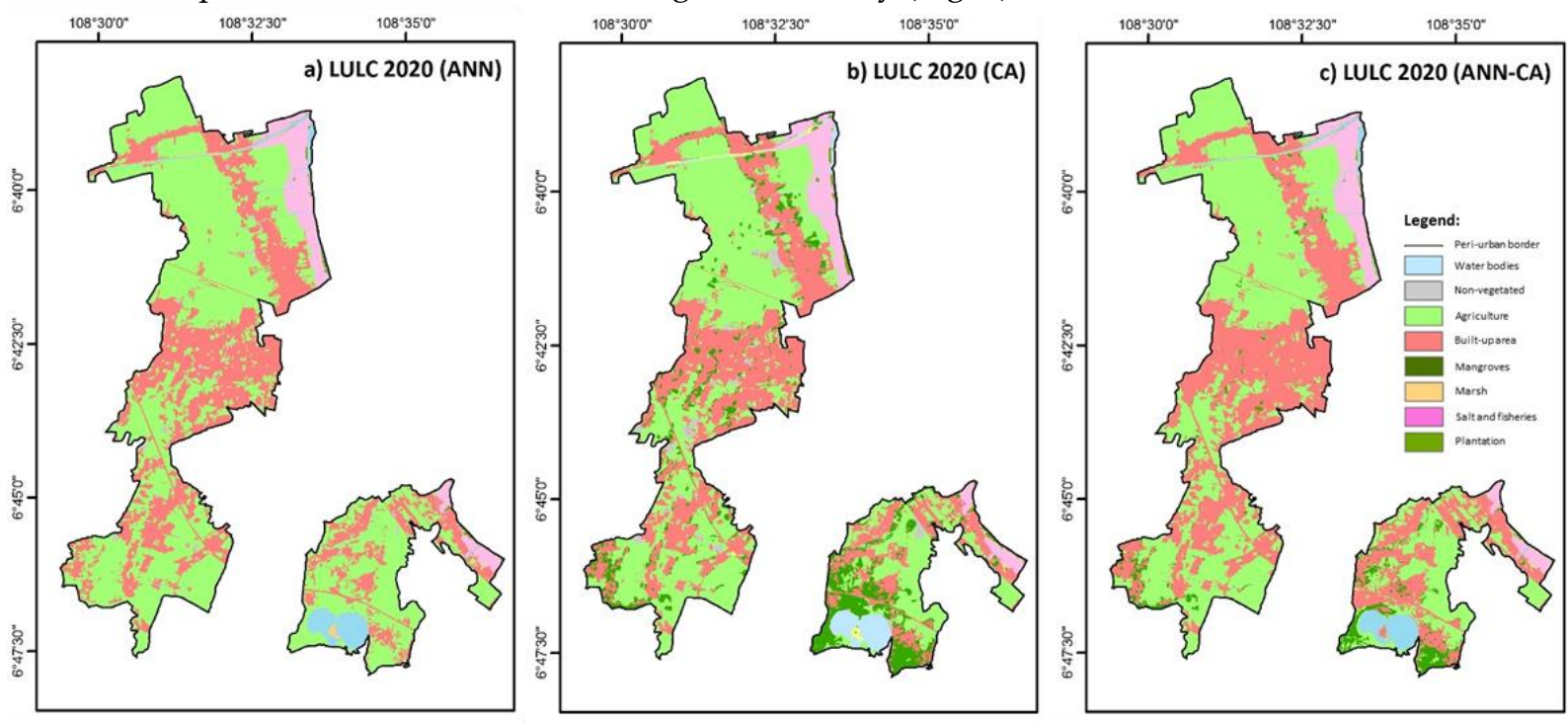

Fig. 5. Comparison of LULC prediction models in 2020
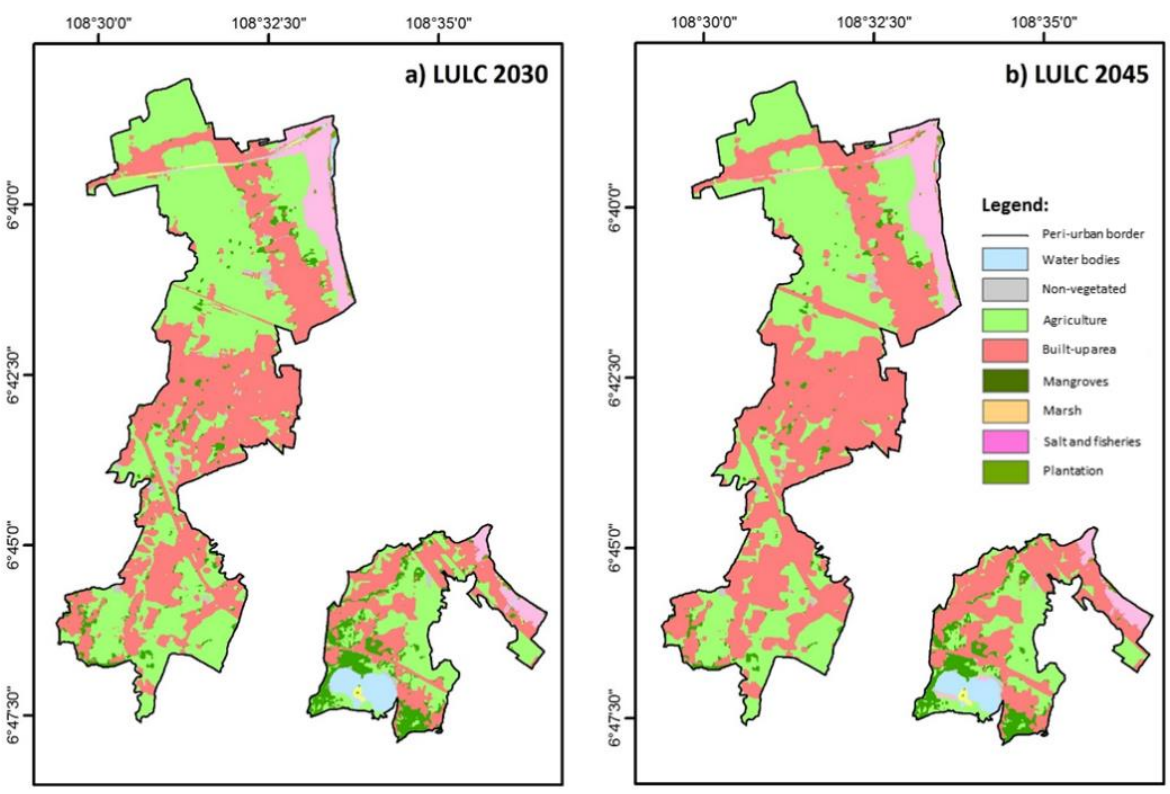

Fig. 6. Future LULC in 2030 and 4045 based on CA model

Table 6. Accuracy comparison between three models of spatial dynamics

\begin{tabular}{llrr}
\hline & \multicolumn{1}{c}{ Spatial dynamics model } & Overall accuracy & \multicolumn{2}{c}{ Overall kappa } \\
\hline ANN & Multi-layer Perceptron Neural Network (MLPNN) & 0.75 & 0.66 \\
CA & Markov-Cellular Automata (Markov-CA) & 0.96 & 0.95 \\
ANN-CA & Multi-layer Perceptron (MLP) & 0.73 & 0.66 \\
\hline
\end{tabular}

The two predicted future LULC periods show that biogeophysical factors such as elevation, land slope, and water bodies in Cirebon's peri-urban have a role as a barrier for built-up expansion. Java Sea as an ecological barrier for the peri-urban has potential to accretion and reclamation for supporting infrastructures development. Control of built-up expansion through compact and ribbon development scheme is a strategy and better solution for controlling urban growth because it is related to spatialdensity patterns as the main key [44]. Compact and ribbon development in Cirebon's peri-urban should be implemented, due to reasons of accessibility, regional interactions with megapolitan areas, and its 
historical aspects $[45,46,47]$. In addition, compact and ribbon development is the path to a sustainable city because it prioritizes urban space efficiency.

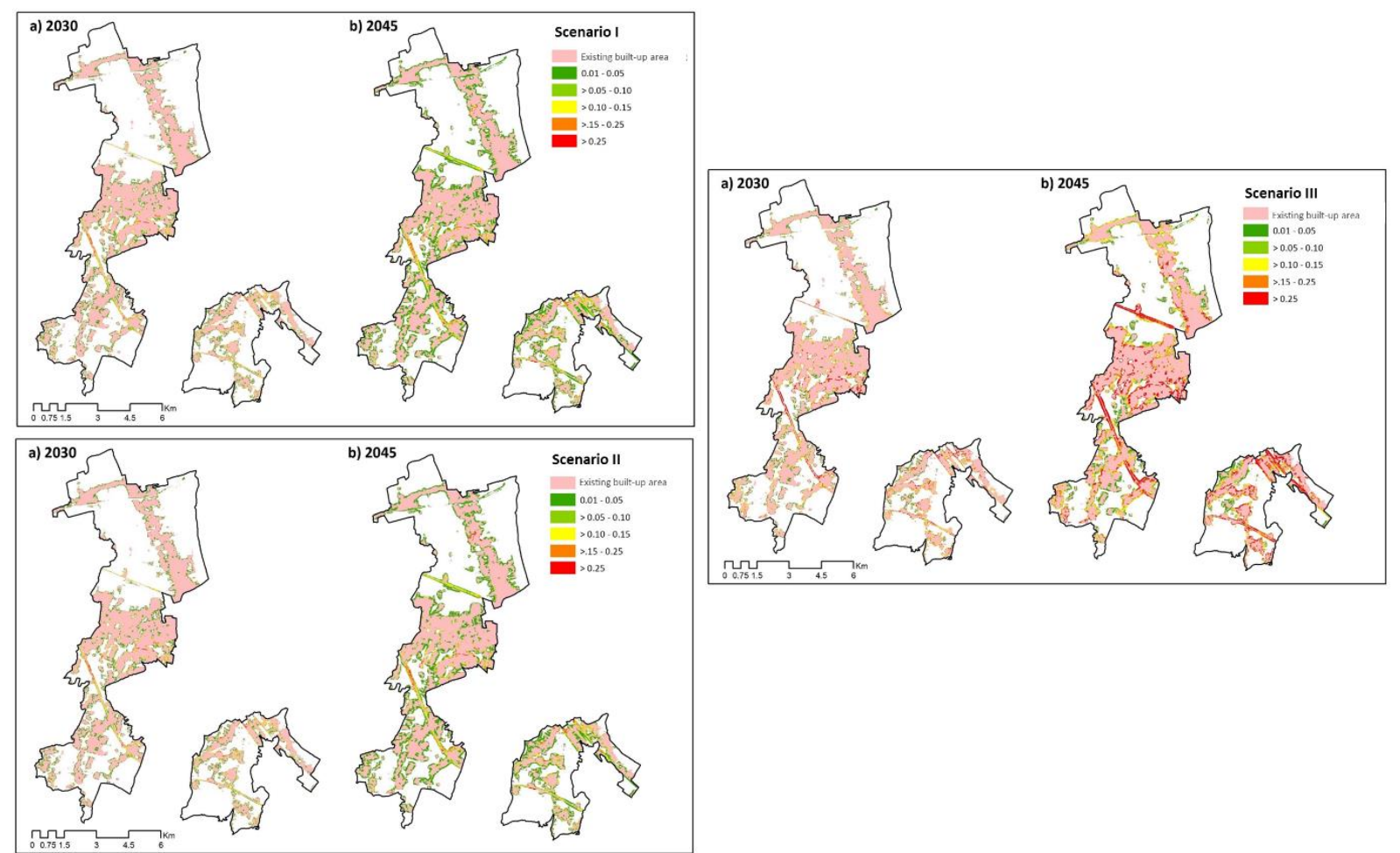

Fig. 7. LULC scenarios and probabilities in the future

Table 7. LULC in the future based on CA

\begin{tabular}{lrrrrrr}
\hline \multirow{2}{*}{ LULC type } & \multicolumn{3}{c}{ Area $\mathbf{( k m}^{2} \mathbf{~}$} & \multicolumn{3}{c}{ Gain and loss $\mathbf{( k m}^{\mathbf{2}} \mathbf{}$} \\
& $\mathbf{2 0 2 0}$ & $\mathbf{2 0 3 0}$ & $\mathbf{2 0 4 5}$ & $\mathbf{2 0 2 0 - 2 0 3 0}$ & $\mathbf{2 0 3 0 - 2 0 4 5}$ & $\mathbf{2 0 2 0 - 2 0 4 5}$ \\
\hline Water bodies & 2.031 & 1.641 & 1.214 & -0.390 & -0.427 & -0.817 \\
Non-vegetated & 1.330 & 0.767 & 0.596 & -0.563 & -0.172 & -0.734 \\
Agriculture & 36.853 & 34.207 & 29.721 & -2.646 & -4.486 & -7.132 \\
Built-up area & 25.002 & 31.058 & 36.961 & 6.056 & 5.903 & 11.959 \\
Mangroves & 0.378 & 0.318 & 0.248 & -0.060 & -0.070 & -0.130 \\
Marsh & 0.285 & 0.229 & 0.181 & -0.056 & -0.048 & -0.104 \\
Salts and fisheries & 3.970 & 4.172 & 4.492 & 0.202 & 0.320 & 0.522 \\
Plantations & 6.980 & 4.436 & 3.416 & -2.544 & -1.020 & -3.564 \\
\hline
\end{tabular}

\section{Conclusion}

LULC dynamics in Cirebon's peri-urban is a transformation process of rural to urban landscape. During 1999-2019, LULC changes were dominated by built-up area expansion. It caused a reduction in plantations and agricultural land. The logistic regression model shows that drivers have simultaneous and significant effects on LULC changes. There are 4 (four) drivers that significantly influence this phenomenon, i.e. land slope, distance from existing built-up area, distance from CBD, and accessibility. The LULC prediction based on cellular automata (CA) algorithm is better than ANN and ANN-CA; built-up expansion is predicted to continue to reaches $31.06 \mathrm{~km}^{2}(2030)$ and $36.96 \mathrm{~km}^{2}(2045)$. The highest probability of LULC changes is shown by the third scenario, where population density is projected to increase and in line with increased accessibility. This scenario has an average probability of 0.18 (2030) and 0.19 (2045). To reveal more urban development through built-up area expansion, we suggest further studies to add social factors as drivers, such as social perceptions, supply-demand of settlements, and population pressure on land.

\section{Author Contributions}

Moh. Dede: Conceptualization, methodology, formal analysis, visualization, and writing - original draft. Chay Asdak: Supervision, methodology, validation, and writing - review \& editing. Iwan Setiawan: Supervision, methodology, validation, and writing - review \& editing. 


\section{Acknowledgment}

The authors would like to thank Dra. Heni Susiati, M.Si., Prof. Parikesit, Dr. Dadan Sumiarsa, and Dr. Sunardi for providing valuable advice on this manuscript. This research was funded by Indonesian Government Research and Funding Grant in 2020, it is managed by Center for Nuclear Energy System Assessment (PKSEN), BATAN amd supported by the 2021 RISTEK/BRIN-LPDP project (14/E1/III/PRN/2020). Also, special thanks to Millary Agung Widiawaty for English improvement of the manuscript.

\section{Declaration of Competing Interest}

We declare that we have no conflict of interest.

\section{References}

[1] R. DeFries, A. Hansen, B. L. Turner, R. Reid and J. Liu, "Land Use Change Around Protected Areas: Management to Balance Human Needs and Ecological Function," Ecological Applications, vol. 17, no. 4, pp. 1031-1038, 2007.

[2] E. F. Lambin and P. Meyfroidt, "Global land use change, economic globalization, and the looming land scarcity," in Proceedings of the National Academy of Sciences, 2011.

[3] A.-A. Kafy, M. N. H. Naim, G. Subramanyam, A.-A.-. Faisal, N. U. Ahmed, A. A. Rakib, M. A. Kona and G. S. Sattar, "Cellular Automata approach in dynamic modelling of land cover changes using RapidEye images in Dhaka, Bangladesh," Environmental Challenges, vol. 4, 2021.

[4] O. Brovkina, F. Zemek, J. Novotný, M. Heřman and P. Štěpánek, "Analysing changes in land cover in relation to environmental factors in the districts of Znojmo and Třebíč (Czech Republic)," European Journal of Environmental Sciences, vol. 7, no. 2, pp. 108-118, 2017.

[5] M. Mastel, A. Bussalleu, V. A. Paz-Soldán, G. Salmón-Mulanovich, A. Valdés-Velásquez and S. M. Hartinger, "Critical linkages between land use change and human health in the Amazon region: A scoping review," PLoS ONE, vol. 13, no. 6, 2018.

[6] M. Dede, M. A. Widiawaty, Y. R. Ramadhan, A. Ismail and W. Nurdian, "Prediksi Suhu Permukaan Menggunakan Artificial Neural Network-Cellular Automata di Wilayah Cirebon dan Sekitarnya," in Seminar Nasional Geomatika 2020, 2020.

[7] Z. Opršal, P. Kladivo and I. Machar, "The role of selected biophysical factors in long-term landuse change of cultural landscape," Applied Ecology and Environmental Research, vol. 14, no. 2, pp. 2340, 2016

[8] J. M. Kamwi, M. A. Cho, C. Kaetsch, S. O. Manda, F. P. Graz and P. W. Chirwa, "Assessing the Spatial Drivers of Land Use and Land Cover Change in the Protected and Communal Areas of the Zambezi Region, Namibia," Land, vol. 7, no. 4, p. 131, 2018.

[9] M. A. Widiawaty, A. Ismail, M. Dede and N. Nurhanifah, "Modeling Land Use and Land Cover Dynamic Using Geographic Information System and Markov-CA," Geosfera Indonesia, vol. 5, no. 2, pp. 210-225, 2020.

[10] S. S. Demograf, "Proyeksi Penduduk Indonesia 2010-2035," Badan Pusat Statistik, Jakarta, 2013.

[11] L. Jiang and Y. Zhang, "Modeling Urban Expansion and Agricultural Land Conversion in Henan Province, China: An Integration of Land Use and Socioeconomic Data," Sustainability, vol. 8, no. 9, p. 920, 2016.

[12] M. A. Widiawaty, N. Nurhanifah, A. Ismail and M. Dede, "The The impact of Cirebon coal-fired power plants on water quality in Mundu Bay, Cirebon Regency," Sustinere: Journal of Environment and Sustainability, vol. 4, no. 3, pp. 189-204, 2020.

[13] L. S. Hasibuan, "Analisis Dampak Konversi Lahan Terhadap Sosial Ekonomi Masyarakat di Kabupaten Deli Serdang," Ekonomikawan: Jurnal Ilmu Ekonomi dan Studi Pembangunan, vol. 15, no. 1, pp. 1-15, 2015.

[14] M. Dede, G. P. Pramulatsih, M. A. Widiawaty, Y. R. Ramadhan and A. Ati, "Dinamika Suhu Permukaan dan Kerapatan Vegetasi di Kota Cirebon," Jurnal Meteorologi Klimatologi dan Geofisika, vol. 6, no. 1, pp. 23-30, 2019. 
[15] M. Dede, C. Asdak and I. Setiawan, "Spatial-Ecological Approach in Cirebon's Peri-Urban Regionalization," in The 4th International Geography Seminar, 2020.

[16] N. G. Dan-Jumbo, M. J. Metzger and A. P. Clark, "Urban Land-Use Dynamics in the Niger Delta: The Case of Greater Port Harcourt Watershed," Urban Science, vol. 2, no. 4, p. 108, 2018.

[17] K. S. Kumar, N. V. A. S. S. Valasala, J. V. V. Subrahmanyam, M. Mallampati, K. Shaik and P. Ekkirala, "Prediction of Future Land Use Land Cover Changes of Vijayawada City Using Remote Sensing and GIS," International Journal of Innovative Research in Advanced Engineering, vol. 2, no. 3, p. 91-97, 2015.

[18] X. Li and A. G.-O. Yeh, "Neural-network-based cellular automata for simulating multiple land use changes using GIS," International Journal of Geographical Information Science, vol. 16, no. 4, pp. 323343, 2002.

[19] S. Karim, "Perubahan perilaku Non-Player Character (NPC) pada Game Arabic Hunter menggunakan Jaringan Syaraf Tiruan Perceptron," Register: Jurnal Ilmiah Teknologi Sistem Informasi, vol. 3, no. 2, pp. 34-41, 2017.

[20] Y. Andriani, H. Silitonga and A. Wanto, "Analisis Jaringan Syaraf Tiruan untuk prediksi volume ekspor dan impor migas di Indonesia," Register: Jurnal Ilmiah Teknologi Sistem Informasi, vol. 4, no. 1, pp. 30-40, 2018.

[21] M. A. Widiawaty, Mari Mengenal Sains Informasi Georafis, Bandung: Aria Mandiri Group, 2019.

[22] D. Sugandi, I. Setiawan and N. Sugito, "Application Remote Sensing to Analysis Bandung Basin Landuse," PONTE, vol. 72, no. 8, pp. 388-399, 2016.

[23] A. Banskota, N. Kayastha, M. J. Falkowski, M. A. Wulder, R. E. Froese and J. C. White, "Forest Monitoring Using Landsat Time Series Data: A Review," Canadian Journal of Remote Sensing, vol. 40, p. 362-384, 2014.

[24] Y.-M. Luo, Y. Ouyang, R.-C. Zhang and H.-M. Feng, "Multi-Feature Joint Sparse Model for the Classification of Mangrove Remote Sensing Images," ISPRS International Journal of Geo-Information, vol. 6, no. 6, p. 177, 2017.

[25] M. A. Widiawaty, N. Nandi and H. Murtianto, "Physical and Social Factors of Shoreline Change in Gebang, Cirebon Regency 1915-2019," Journal of applied geospatial information, vol. 4, no. 1, pp. 327-334, 2020.

[26] S. R. P. Sitorus, C. Leonataris and D. R. Panuju, "Analisis Pola Perubahan Penggunaan Lahan dan Perkembangan Wilayah di Kota Bekasi, Provinsi Jawa Barat," Jurnal Ilmu Tanah dan Lingkungan, vol. 14, no. 1, pp. 21-28, 2012.

[27] A. Ismail, M. Dede and M. A. Widiawaty, "Urbanisasi Dan HIV di Kota Bandung (Perspektif Geografi Kesehatan)," Buletin Penelitian Kesehatan, vol. 48, no. 2, pp. 139-146, 2020.

[28] N. H. Asnawi and L. K. Choy, "Analisis Perubahan Guna Tanah dan Litupan Bumi di Gombak, Selangor Menggunakan Data Penderiaan Jauh," Sains Malaysiana, vol. 45, no. 12, p. 1869-1877, 2016.

[29] S. H. A. Jarah, B. Zhou, R. J. Abdullah, Y. Lu and W. Yu, "Urbanization and Urban Sprawl Issues in City Structure: A Case of the Sulaymaniah Iraqi Kurdistan Region," Sustainability, vol. 11, no. 2, p. 485, 2019.

[30] S. N. Mohapatra, P. Pani and M. Sharma, "Rapid Urban Expansion and Its Implications on Geomorphology: A Remote Sensing and GIS Based Study," Geography Journal, 2014.

[31] B. M. Brebante, "Analyzing the Effects of Land Cover/Land Use Changes on Flashflood: A Case Study of Marikina River Basin (MRB), Philippines," University of Twente, Enschede, 2017.

[32] B. Mienmany, "Analysis land use and land cover changes and the driving forces: A case study in Kaysone Phomvihan District, Laos," University of Porto, Porto, 2018.

[33] A. Willige, "The UN says climate-smart cities are the future - these 3 projects show their potential," World Economic Forum, 2020. [Online]. Available: https://www.weforum.org/agenda/2020/09/climate-change-resilience-urban-infrastructure. 
[34] K. Farrell, "The Rapid Urban Growth Triad: A New Conceptual Framework for Examining the Urban Transition in Developing Countries," Sustainability, vol. 9, no. 8, p. 1407, 2017.

[35] S. Wilonoyudho, R. Rijanta, Y. T.Keban and B. Setiawan, "Urbanization and Regional Imbalances in Indonesia," Indonesian Journal of Geography, vol. 49, no. 2, pp. 125-132, 2017.

[36] M. A. Widiawaty, G. P. Pramulatsih and V. Pebriani, "Jaringan Transportasi dan Pengembangan Destinasi Pariwisata di Kota Cirebon," in The 6th Travel Industry Student Forum (TISF), Bandung, 2018.

[37] J. Lahti, "Modelling Urban Growth Using Cellular Automata: A case study of Sydney, Australia," The International Institute for Geo-informations Science and Earth Observation, Enschede, 2008.

[38] D. W. Hosmer and S. Lemeshow, Applied Logistic Regression, John Wiley \& Sons, 2000.

[39] A. M. R. Patiwiri, "Alih Fungsi Tanah Pertanian Untuk Pembangunan Perumahan di Kabupaten Luwu Timur," Universitas Hasanuddin, Makassar, 2013.

[40] S. S. Rwanga and J. M. Ndambuki, "Accuracy Assessment of Land Use/Land Cover Classification Using Remote Sensing and GIS," International Journal of Geosciences, vol. 8, no. 4, p. 611, 2017.

[41] A. Al Kafy, M. S. Rahman, A. Al Faisal, M. M. Hasan and M. Islam, "Modelling future land use land cover changes and their impacts on land surface temperatures in Rajshahi, Bangladesh," Remote Sensing Applications: Society and Environment, vol. 18, 2020.

[42] Y. Liu and Y. Feng, "A Logistic Based Cellular Automata Model for Continuous Urban Growth Simulation: A Case Study of the Gold Coast City, Australia. 2012 Agent-Based Models of Geographical Systems," in Agent-Based Models of Geographical Systems, A. J. Heppenstall, A. T. Crooks, L. M. See and M. Batty, Eds., Dordrecht, Springer, 2012.

[43] Z. Shahbazian, M. Faramarzi, N. Rostami and H. Mahdizadeh, "Integrating logistic regression and cellular automata-Markov models with the experts' perceptions for detecting and simulating land use changes and their driving forces," Environ Monit Assess, vol. 191, no. 422, 2019.

[44] G. W. Laskara, "Strategi Implementasi Konsep “Compact City” Menuju Pengembangan Kawasan Perkotaan Berkelanjutan," in Seminar Nasional Konsepsi \#2, Denpasar, 2016.

[45] A. Hasdaniati, "Studi Pola Perkembangan Perkotaan Berdasarkan Morfologi Ruang Di Kota Bantaeng," Universitas Islam Negeri Alauddin Makassar, Makassar, 2014.

[46] T. Verbeek and B. Tempels, "Measuring fragmentation of open space in urbanised Flanders: an evaluation of four methods," Belgeo. Revue belge de géographie, vol. 2, 2016.

[47] S. Brody, "The Characteristics, Causes, and Consequences of Sprawling Development Patterns in the United States," Nature Education Knowledge, vol. 4, no. 5, p. 2, 2013. 